\title{
Kuwait and the Northern Arabian Gulf: A Study in Quaternary Sedimentation
}

\author{
by Ananda Gunatilaka
}

Considerable progress has been made in the last 25 years on the geology of the northern Arabian (Persian) Gulf, though most of the subsurface data is not publicly available. This review summarizes the Pleistocene pluvial events and eustatic sea-level changes that have played a major role in shaping the evolution of this region. It is an area of two major and contrasting sedimentation styles in a low-relief desert margin system, bordering a hypersaline sea.

\section{Introduction}

The discovery of the huge Mesozoic carbonate reservoirs of the Middle East paved the way in the early 1960s for the opening up of the southern Arabian Gulf as a laboratory for modern carbonate research. This was a landmark in regional sedimentation studies, mainly because of the efforts of research groups from the Koninklijke Shell Company and V.C. Illing and Partners (see Purser, 1973). Some of this work still remains unpublished. Studies by D.J. Shearman and co-workers from Imperial College London of the supratidal sediments that formed here under arid conditions on the extensive coastal plains led to the formulation of the sabkha model as a new tool for facies analysis (Kinsman, 1969; Purser, 1973). This opened up new vistas of research into the geochemistry and diagenesis of dolomite and sulphate facies evaporites associated with carbonates.

The impact of this pioneering work was immediate, revolutionary and far-reaching, and the sabkha model was soon invoked for many limestones associated with evaporites. The enthusiasm almost obscured the fact that the Trucial Coast region of the United Arab Emirates (UAE), where this early work was carried out, represents only $20 \%$ of the entire $226,000 \mathrm{~km}^{2}$ of the Gulf basin. Much of the Saudi Arabian and Kuwait coastlines, the Euphrates-Tigris-Karun (Shatt Al-Arab) delta region and almost the entire Iranian side of the Gulf remained uninvestigated until very recently.

In 1980, the Department of Geology at Kuwait University began a six-year research program to investigate the Quaternary marine and continental sediments of Kuwait in the northwestern Arabian Gulf (Fig. 1). Simultaneously, an exhaustive study was carried out on Bubiyan Island at the head of the Gulf and the western extremity of the Holocene sediments of the delta region (Al-Zamel, 1983). These two regional studies compliment the now well-established studies from the southern Gulf and fill an important gap in our knowledge of the whole region. In addition, new work along the Saudi Arabian coastal zone shows that the Trucial Coast region of the $\mathrm{UAE}$ is neither representative nor typical of the $1,000 \mathrm{~km}$-long Arabian Gulf - indeed, no single geographical area exemplifies the whole coast.
Considerable variation in sedimentation styles exists within the Gulf and Peninsula, and all of these should be utilized in ancient facies analysis.

\section{Regional Geological Setting}

The northwestern Arabian Gulf is located on the eastern stable shelf of the Arabian platform, which dips to the northeast at $1-2^{\circ}$. The platform is bordered on the northeast by the Zagros mountain belt, which forms part of the Alpine-Himalayan chain produced as a result of continental collision during Late Cretaceous to Viocene times (KamcnKaye, 1970; Murris, 1980). This suture zone is a consequence of the subduction and closure of the Tethys ocean (Sengor, 1985).

The main structural features of the northwestern Arabian Gulf have resulted from epeirogenic movements. These are indicated by the Burgan, Magwa, Ahmadi, Raudhatiin, Sabiriyah and Managish structural highs and several of shore structures such as the Hout anticline (Fig. 1). Most of the

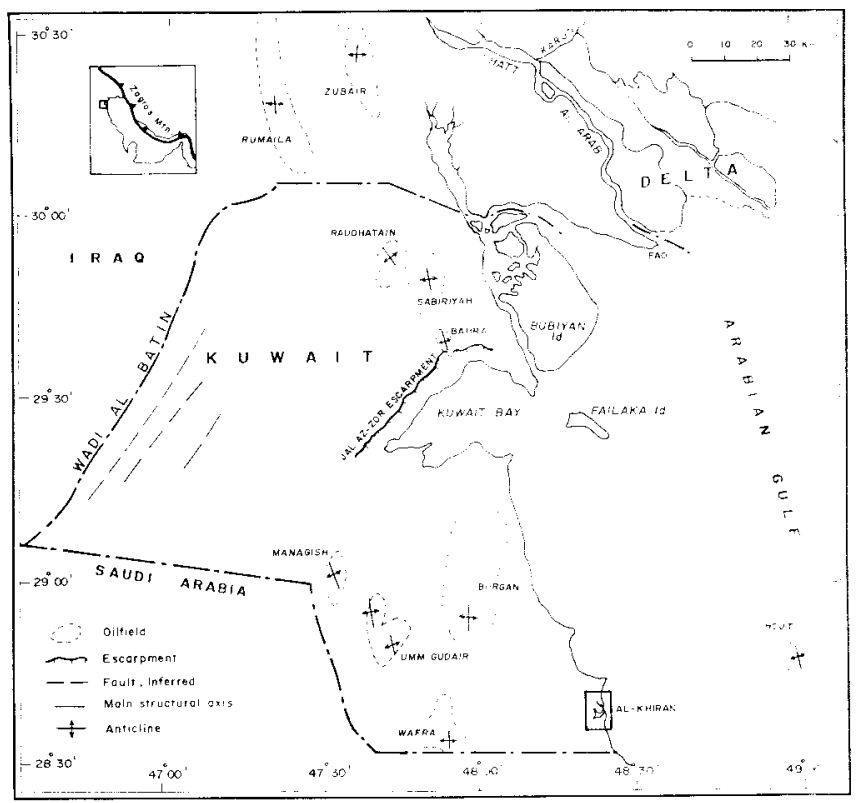

Figure 1: Location of major structural and geomorphic features in the northern Arabian Gulf. Box at Al-Khiran shows Southern Kuwait study area described in text. 
major regional structures trend north-northwest and are thought to be produced by salt tectonism (Murris, 1980) or as growth folds that began to form during Jurassic times and continued to develop until the late Tertiary (Kamen-Kaye, 1970; Behbehani, 1980). Several normal faults displace these folds. Most of the major oil fields in this area lie along this NNW trend, which continues all the way to the southern Gulf. The interaction of the Arabian folds and those of the Zagros Mountains is reflected in the submarine topography of the Gulf (Kassler, in Purser, 197.3).

Stable shelf conditions have prevailed in the area since Paleozoic and early Mesozoic time, with the rate of subsidence and sediment supply keeping pace and resulting in very thick, shallow-water sequences dominated since late Paleozoic times by platform carbonates. Short periods of uplift in the Arabian Shield in response to major plate movement during the Early Cretaceous eaused deposition of mature sandstones and shales such as the Burgan and Wara sandstones (deltaic reservoir facies) and Ahmadi shales (source rocks?) of Albian-Cenomanian age. Thick evaporites were also deposited in restricted basins during periods of low detrital influx (the Gothnia Formation of Kimmeridgian to Tithonian age). During Miocene time, a peripheral basin formed to the northwest of the Zagros belt, covering the present day territories of the northwestern Gulf and Peninsula. Continental clasties shed from the eastern and western highlands filled this shallow basin with the Ghar, Lower Fars and Dibdibba Formations of Miocene-Pleistocene age.

Several major episodes of uplift and erosion occurred during Early Jurassic (Hettangian) to Oligocene (Chattian) time. The number and duration of the deformation phases increases towards Saudi Arabia (where the shelf becomes shallower) and decreases towards the north-northeast, where deeper basins extending into the Tethys prevailed. The resulting regional unconformities are seen in most of the major structures mentioned above (Murris, 1980).

Most of Kuwait's oil is in Middle Cretaceous sandstones, with some also in Lower Cretaceous limestones. The main oil-bearing structures are doubly plunging anticlines and domes, with Burgan alone (containing the second largest onshore oilfield in the world) accounting for recoverable reserves estimated by Schlumberger Technical Services Inc. in excess of 87 billion barrels (Schlumberger, 1986). The Safania-Khafji field in the neutral zone between southern Kuwait and Saudi Arabia is the world's largest off shore field with reserves exceeding 38 billion barrels (ibid).

\section{The Euphrates-Tigris (Shatt Al-Arab) Delta}

The Euphrates-Tigris or Shatt Al-Arab delta and fluvial system is a classical example of a grain-parallel drainage system bordering a foldbelt. Structurally, this system is associated with the complex Mesozoic-Cenozoic Zagros orogenic belt, with an Alpinotype subduction zone boundary (or A-Zone according to Bally, 1975), now largely aborted. Like many other large deltas, the Shatt Al-Arab is located where an A-Zone intersects the coast. Many deltas of this type pass across the continental margin onto the ocean floor. The Shatt Al-Arab, however, is over $1,000 \mathrm{~km}$ from the continental margin and, therefore, represents an early stage in the evolution of this type of A-Zone delta (Audley-Charles et al., 1977). It will eventually reach the Indian Ocean margin with the filling or tectonic closure of the Gulf basin. A-Zone intracratonic deltas like this are preserved in the geological record in a less deformed state compared to other deltas developed along similar megasutures (ibid.).

The Mesopotamian delta plain has been continuously inhabited for over 5,000 years and has a rich and well documented archaeological record. It is probably the only modern example of a delta opening into a hypersaline, semienclosed marine basin and bordering a desert. Yet, the geomorphology, Quaternary stratigraphy and Holocene development of this region are poorly known. The Quaternary geological history and evolution of the delta itself is a controversial subject with several divergent opinions (Lees and Falcon, 1952; Hudson et al., 1957; Larsen and Evans, 1978).

Two opposing views prevail, which involve substantial growth and subsidence as against insignificant growth of the delta during the Holocene. It is not possible at this stage to reach any definite conclusions due to the scarcity of published data, inadequate understanding of recent tectonism, sea-level changes and sedimentation in the delta region. A planned delta research project was abandoned with the outbreak of the Gulf war.

Major tectonic movements during the Late Pleistocene and Holocene have apparently been ruled out by evidence from the adjacent Gulf area and, by implication, in the delta also (Kassler, in Purser, 1973), but recent unpublished studies have reconsidered this possibility. Moreover, it is likely that significant subsidence due to compaction has occurred. Fluctuations in sea-level, therefore, appear to be the major factor in shaping the evolution of this region, and it has been suggested that up to $200 \mathrm{~km}$ of delta progradation has occurred since the last Holocene sea-level maximum about 5,000 yBP (Larsen and Evans, 1978). However, maps showing the limits of this transgression or a precise radiocarbon chronology of known Quaternary sequences are still not available.

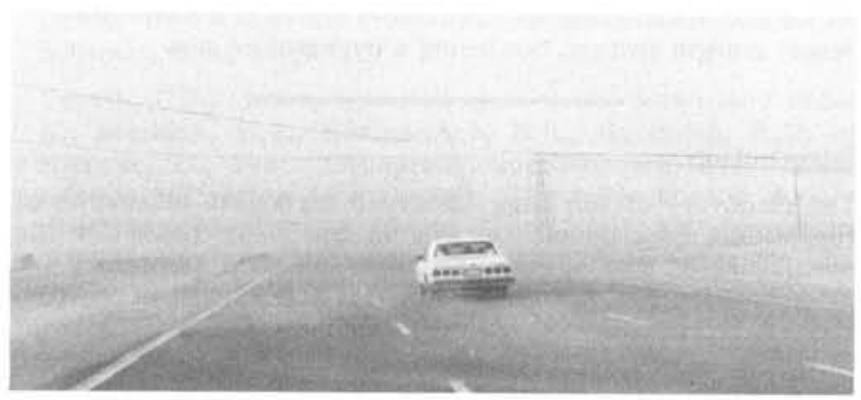

Figure 2: A winter dust storm along the coastal highway of southern Kuwait. Eolian contributions to the marine environment are significant.

The records of the Sumerians (circa. 3500-2000 B.C.) show that the ancient cities of Ur and Eridu to the northwest of Fao (Fig. 1) were historically linked to the sea, but now lie some $100 \mathrm{~km}$ from the present shoreline. A single ${ }^{14} \mathrm{C}$ date of $9910 \pm 110 \mathrm{yBP}$ from a freshwater-marsh mud collected from $-32 \mathrm{~m}$ in the $\mathrm{Fao}$ peninsula reflects the Holocene transgression discussed later and almost certainly rules out any Holocene tectonic subsidence in the delta (Larsen and Evans, 1978). Most probably, erosional and depositional events, and changes in climate, sea-level and cultural practices (especially irrigation) during the last 5,000 years have all played their part in delta growth and evolution.

Today, it appears that the northern Gulf basin receives very little sediment from river systems, much of the detritus being trapped upstream in the marshes. Large sediment plumes in the Gulf can be seen in satellite pictures only during, and soon after, the rainy season. For most of the year estuarine conditions prevail.

\section{Contrasting Styles of Sedimentation}

Within the $200 \mathrm{~km}$-long coastal zone of Kuwait, two contrasting styles of sedimentation can be seen. The northern portion has been very much under the influence both of clastic sediment input from the Euphrates-Tigris-Karun multiple delta system into the northern Gulf basin and of the pattern of counter-clockwise tidal currents that dominate water movements. 
In contrast, the southern coastal zone is a classic carbonate "ramp" with a subtidal carbonate factory generating sediments within the basin of deposition itself. Deltaic influence is minimal here, having died out within the first $100-120 \mathrm{~km}$ south of the delta shoreline. With increasing distance offshore, the carbonate sediments grade into siliciclastics, signifying the influence of the Zagros orogenic zone along the eastern boundary of the Gulf. The carbonate-clastic transition can be traced both alongshore and offshore, providing an excellent opportunity to study the regional variation of the sedimentary framework in this important region.

\section{The Northern Coastal Zone}

Several pioneering studies have been completed recently on this area (Al-Asfour, 1982; Al-Zamel, 1983; Reda, 1986). The most significant study is by Al-Zamel on the geology, oceanography, sedimentology and Holocene history of Bubiyan Island, an area of vital significance because it is the westernmost region of the Euphrates-Tigris delta at the northwestern extremity of the Gulf (Fig. 1). The island is bare, uninhabited and until very recently was approachable only at high tide, and this study took six years to complete due to problems of accessibility, logistics and climate.

A clastic, tidal flat-sabkha complex and a unique tidal regime characterises the mesotidal (range of tides between 2 and $4 \mathrm{~m}$ ) coastline of northern Kuwait. Maximum flooding of the supratidal zone is dependent on the coincidence of high spring and/or storm tides with southeasterly winds, a very rare situation occurring not more than once or twice a year. The prevailing wind from the northwest (the shamal) results in a very narrow strip $(0.6-0.7 \mathrm{~km}$ wide) of the tidal zone being subjected to flooding during the normal tidal cycle. The area can therefore be described as a wind tidal-flat (Reda, 1986).
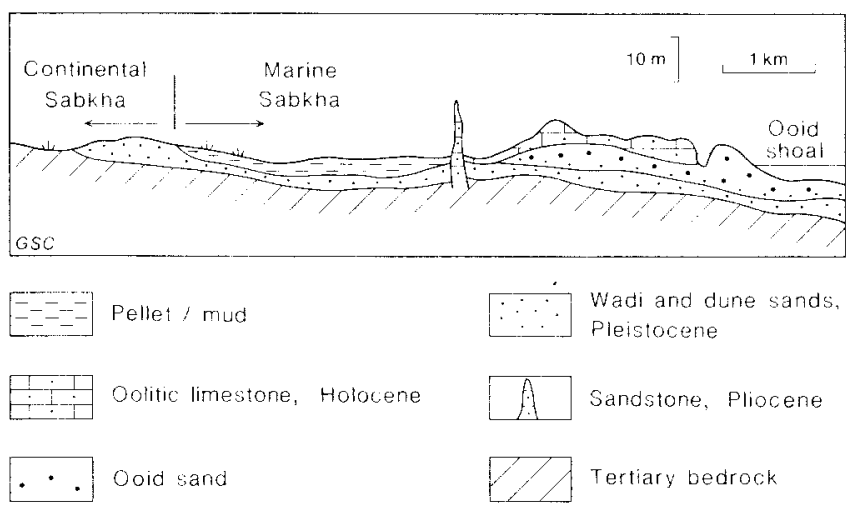

Figure 3: A generalized section from coast to desert in the Al-Khiran area.

The sediments are rich in detrital, silt-sized carbonates. Since the coastal areas are bordered by a hypersaline water body, biological activity is limited in the tidal zones. As a result most of the internal sedimentary structures are preserved, with minor disruption caused by intra-sedimentary gypsum growth. Progradation of the coastline has been going on since about $3040 \mathrm{yBP}$ at an annual rate of approximately 1.5 to $2 \mathrm{~m}$.

In the northern part of the Gulf basin, the origin of the fine-grained mud and silt fraction is somewhat controversial (Pilkey and Noble, 1966). A significant proportion of this fraction is carbonate (mostly low-llg calcite and some dolomite), generally believed to have formed through fluvial influx from the Shatt Al-Arab, with minor orthochemical precipitation (Purser, 1973; Stoffers and Ross, 1979).
Recent work by Ellis and Milliman (1985) has shown that the suspended materials in these waters are dominantly detrital carbonates and that there is no evidence for direct precipitation.

The picture has changed somewhat as a result of an intensive research program carried out in Kuwait on eolian dust fallouts (Fig. 2) in the northern Gulf (Kukal and Saadallah, in Purser, 1973; Ministry of Public Health, 1978; Khalaf e: al., 1980, 1982). The dust composition is mainly silt-size calcite, auartz, dolomite and feldspar, which is brought $t$ the area by the prevailing shamal winds from the more remote regions of the Kuwaiti and Iraqi deserts (Al-Bakri et al., 1984). The dolomite grains are detrital and are not formed in Gulf waters. On the other hand, the clays of the delta and tidal flats are also present in suspension in the Tigris and Euphrates rivers (Berry et al., 1970; Al-Zamel, 1983, Reda, 1986). The Euphrates cuts through limestono terrains in Turkey, Syria and Irag, ultimately deliverint some of the sediment load to the delta and the head of the Gulf. The eolian detrital-carbonate fraction may not be as volumetrically important as that derived fluvially, bu: recent estimates suggest that their respective contribution. are at least of the same order of magnitude (Al-Bakri et al. 1984; see also Kukal and Saadallah, op.eit.).

The counter-clockwise currents in the northern Gulf rewori these sediments, transporting them to the Kuwait Bay area, and the daily tides deliver this material to the coastal environments of the region. As a result the tidal flats anc sabkhas are rich in mud-sized carbonate clastics, a situation that raises warning for those interpreting similar ancient analogues. The coarse fraction in the marine environments is minor and is mainly auartz sand, locally derived through wind transport from the nearby Jal Az-Zor escarpment that for ms a prominent backdrop up to $140 \mathrm{~m}$ high to the coastal zone (Fig. 1).

The river Karun and other tributary streams originating i the Zagros Mountains add their sediment loads to the eastern part of the Gulf basin. Very little is known of this side of the basin, but some interesting sabkha association: have been reported from the northeastern coastline of the Gulf (Purser, 1985).

The northwestern coastline of Kuwait was not always dominated by the delta system. Prior to the deposition of the clastic muds and silts at the surface, allochemical carbonate sedimentation prevailed, as evidenced by ooids and pellet-muds at the base of the clastic Holocene section in some places (Reda, 1986). This "sub-Recent" change in sedimentation pattern can be related to Quaternary sea-level and climatic changes in the delta area. Today, the locus of carbonate deposition has shifted to the south, away from the influence of the Shatt Al-Arab.

\section{The Southern Coastal Zone}

The carbonate-dominated southern coastal zone is better known than the northern portion. The first studies were carried out by Saleh $(1975,1979)$ and Picha and Saleh $(1977)$ on the Quaternary deposits, and on the morphology, ecology and distribution of recent cyanobacterial (algal) mats and stromatolites of the Al-Khiran region (Fig. 1). Picha (1978) also made a preliminary study of the sabkhas and oolite deposits of the same area and recognized the region as an arid-zone analog of a chenier plain (beach-dune ridges). Ho regarded the coastal oolitic limestone ridges as Pleistocene in age and postulated that Quaternary tectonic events have influenced the sedimentation pattern. More recent work (1980-1985) by the Kuwait University Sedimentary Research Group has, however, not confirmed the influence of Quaternary tectonics. The broader aspects of this latter study are summarized below.

The network of of fshore islands, shoals and reefs that protect the shorelines of the southern Arabian Gulf are absent in the north, which is consequently a higher energy coast- 


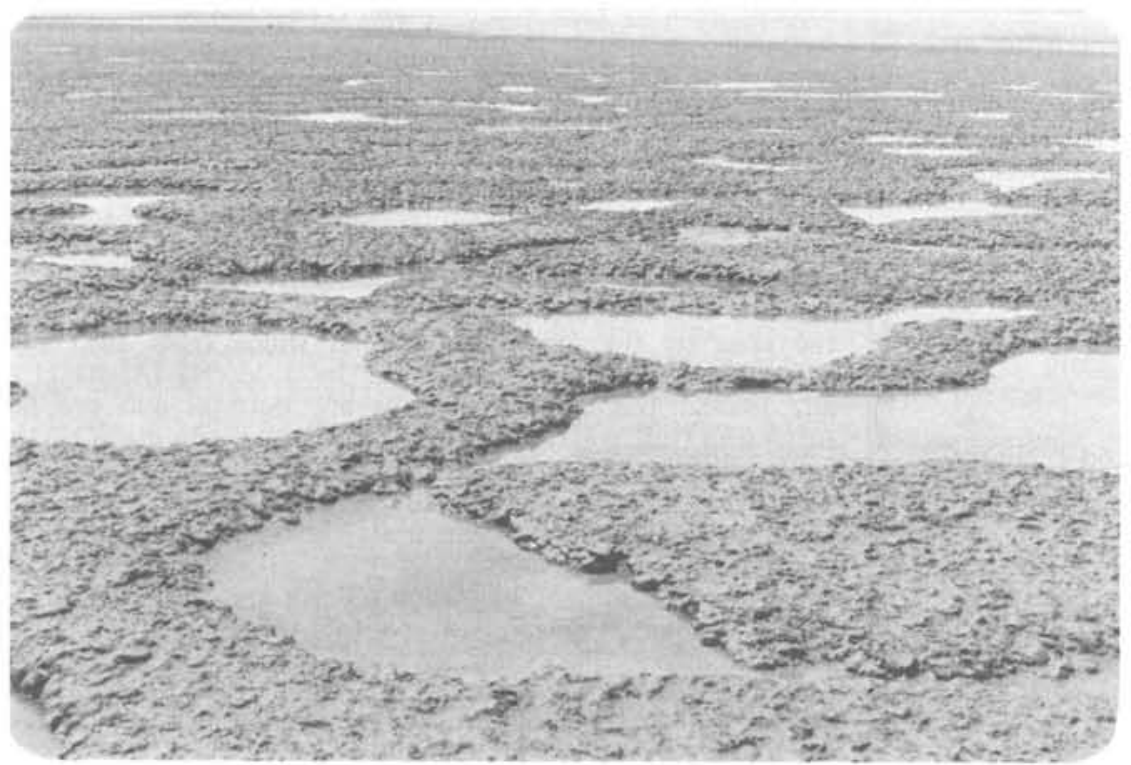

weather base. A well-developed hardground surface is present with a restricted sand-flat biota. Lagoonal facies are minor.

- A lower energy skeletal packstone-wackestone facies forming in depths of up to $20 \mathrm{~m}$ of water. Isolated buildups may oceur in shallow parts of the ramp in the form of small patch-reefs. Larger patch-reefs occur in the deep$\mathrm{er}$, offshore areas $(15-25 \mathrm{~km}$ offshore) on buried topographic highs. The biota is open marine in character.

- Slope and basin facies limemuds, which are highly reducing, and exhibit a restricted biota.

Within this framework, there are two related problems. The first concerns the origin of dolomite. Diagenetic

Figure 4: Intertidal to lower supratidal algal mats forming along a major tidal creek cutting through the Kuwait sabkha. The large pools are $1-1.5 \mathrm{~m}$ across.

line. In addition, the Shamal wind blows offshore in the northern Gulf but onshore in the UAE. The sedimentary framework in southern Kuwait is composed of a complex of ooid shoals, small lagoons, tidal creeks, cheniers and coastal sabkhas, backed by an eolian terrain consisting of gravel plains, sand sheets and inland sabkhas (Fig. 3). The coastal zone of southern Kuwait and extending into Saudi Arabia (Fig. 1) is an excellent example of a carbonate platform of the homoclinal ramp type with a fringing ooid-shoal bar complex along the coast. The shallow, wave-agitated, nearshore shoal complex passes offshore without a break in slope into lower energy carbonate silts and muds.

The coastal belt contains the following facies zones in seaward sequence: subtidal dolomite is now forming here in a small, hypersaline lagoon within aragonite mud-rich sediments where the porewaters have $\mathrm{SO}_{4}$ concentrations significantly lower than that in open marine waters (Gunatilaka et al., 1984, 1985). Dolomite is also present within the sabkhas, but in relatively small amounts. This spareity was surprising at first, but ${ }^{14} \mathrm{C}$-dating has resolved the problem.

In the absence of regular marine flooding and recharge dolomitization is not possible, and today the marine sabkhas are almost completely isolated from the open marine waters due to the presence of four oolitic beach-dune ridges (Gunatilaka et al., 1980). Sedimentary structures show that the first two ridges originated as offshore bars during the Holocene transgressive phase. Both ridges had emerged by $5000 \mathrm{yBP}$, restricting the inflow of marine waters into the back-barrier lagoon. The lagoon emerged very quickly and developed into a sabkha, which was cut off from the open sea. In the sabkha environment, both hypersaline waters and a high flow rate through the sediments are essential for dolomitization. Neither of these conditions existed here and
- An intertidal-supratidal sabkha complex (1-3 km wide) with carbonate pellets and muds, algal mats and evaporites, bordered on the landward side by fluvial-eolian siliciclastics and evaporites (Fig. 4).

- A chenier-belt (0.5-2 km wide) of oolitic beachdune ridges of Holocene age (Fig. 5).

- A subtidal (or peritidal) highenergy, fringing, ooid-shoal bar complex up to $7 \mathrm{~km}$ wide, with water depths up to $6 \mathrm{~m}$. The bottom is above stormwave base, but below fair-

Figure 5: The oldest $\quad(\approx 5500$ $y B P)$ beach-dune ridge of the Al-Khiran area, with a thin calcrete crust on top and karstlike features. Hammer on rock face for scale.

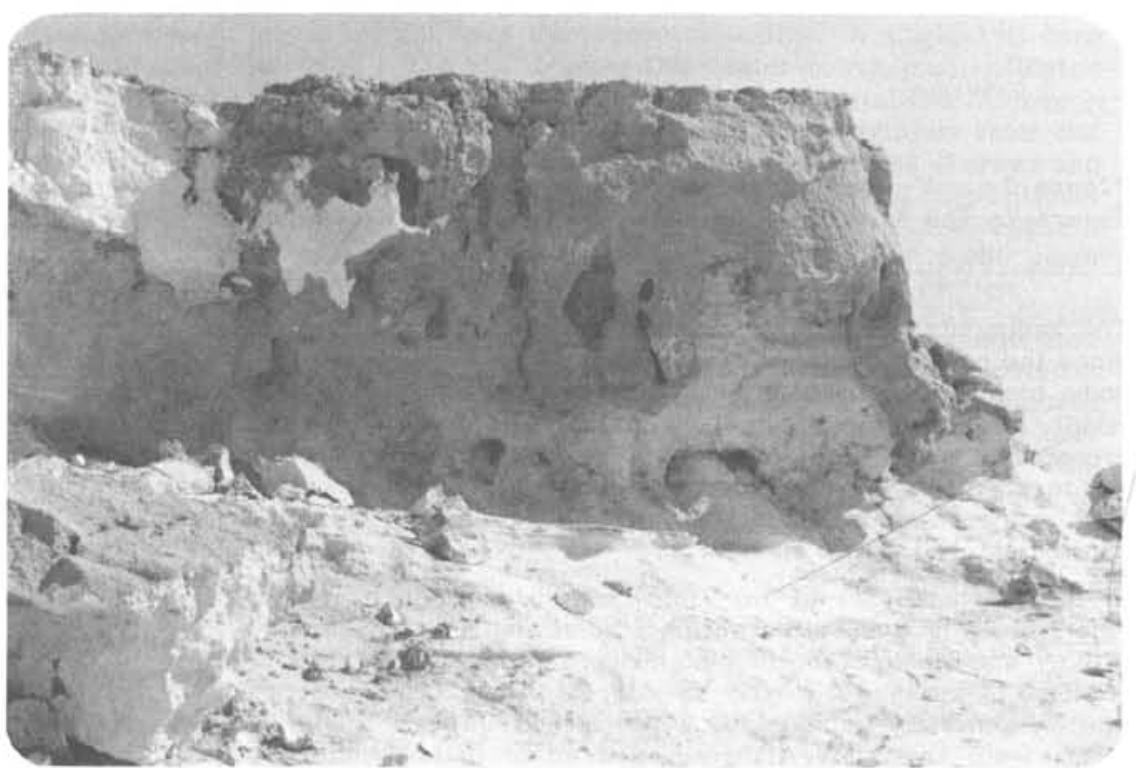


Figure 6: The three lower coastal terraces along the north coast of Kuwait.

dolomitization was therefore minimal. Today, the hydrological regime of these sabkhas is controlled by continental groundwater influx.

The second problem concerns the occurrence of supratidal anhydrite. The Al-Khiran area marks the limit of the anhydrite-bearing evaporite belt in the Gulf. Anhydrite is not found here north of $29^{\circ}$ latitude and is totally absent in the northern sabkhas. This area is also the northernmost limit of coral reefs in the Gulf. Anhydrite is here a diagenetic evaporite phase formed from earlier gypsum. The genesis of anhydrite is associated with either a halophytic plant (Halocnemum strobilaceum) and/or a bacterial-cyanobacterial mat (Gunatilaka et al., 1980); in their absence it does not appear to form. Recent work has shown that during years of excessive rainfall, the anhydrite reverts back to gypsum.

\section{Quaternary Sea-Level Changes}

A detailed investigation by Al-Asfour (1982) into changes of sea level along the north coast of Kuwait addresses the issue of subsidence and tectonism in the area. Sea-level changes were investigated by examining the six coastal terraces along Kuwait Bay (Fig. 6), and by ${ }^{14} \mathrm{C}$ dating of shells from the lower four terraces. During the last five years over one hundred and fifty ${ }^{14} \mathrm{C}$ age determinations have been made in the northwestern Gulf. Al-Asfour's dates comprise two groups: $42,850-23,300 \pm 600$ yBP and $4,570-3,250 \pm 80$ yBP.

The older dates pose several problems. These do not always correspond to the highest terrace elevations (varying from $40-42 \mathrm{~m}$ to $63.3 \mathrm{~m}$ above Kuwait datum), and it is suspected that substantial mixing and contamination of dated material has occurred within the upper four terraces. The younger dates relating to the two lower terraces (5.99-16.1 m above datum) are more consistent and correlatable with other similar dates in the area by Al-Zamel (1983) and the author (unpublished).

During the late Wurm glaciation, global sea-levels were $100-120 \mathrm{~m}$ lower than today. Since the maximum depth of the Gulf does not exceed $100 \mathrm{~m}$, it could have been a dry basin except for the Shatt Al-Arab waterway, which would have then emptied into the Gulf of Oman. That the Gulf experienced continental conditions during the last glacial maximum $(70,000-17,000 \mathrm{yBP})$ is well documented from several lines of evidence (Sarnthein, 1972; Purser, 1973; unpublished data from oil companies).

The Holocene (Flandrian) transgression apparently began at the end of a long and widespread fluvial-eolian phase of the Pleistocene. The history of this transgression and the subsequent rise in sea-levels (Fig. 7) are reasonably well known (Stoffers and Ross, 1979; Al-Asfour, 1982). The oldest Holocene date $(9910 \pm 100 \mathrm{yBP})$ from the Fao peninsula relates to a freshwater, organic detrital mud layer at $-32 \mathrm{~m}$, which replotted on the Fairbridge (1961) scale falls within the range of -29 to $-37 \mathrm{~m}$ (Godwin and Willis, 1959). Likewise, a freshwater, lacrustrine marsh peat at $20-28 \mathrm{~m}$ below mean sea-level has been found in the northern part of Bubiyan Island.

Al-Zamel (1985) has given ${ }^{14} \mathrm{C}$ dates on freshwater peats at $8490-7870 \pm 90 \mathrm{yBP}$, corresponding to depths of $-24.5 \mathrm{~m}$, $-24 \mathrm{~m}$ and $-20 \mathrm{~m}$ respectively, below mean sea-level. The occurrence of peats in an area now characterized by extreme aridity is of great significance in reconstructing the climatic and environmental development of this region

and delineating ancient shorelines in the northern Gulf. Al-Zamel (ibid.) has demonstrated that Bubiyan Island had emerged by $4,500-3,500$ yBP. On its southern shoreline, facing the Gulf, multiple shelly beach ridges have been dated at $3,500-2,800 \mathrm{yBP}$, and Al-Zamel estimates that the coast is prograding here at an average rate of $14-16 \mathrm{~m}$ every 100 years and that the sedimentation rate in the delta offshore is some $36 \mathrm{~cm}$ per 1,000 years. On the other hand, for the adjacent mainland sabkhas Reda (1986) suggests progradation rates of about $1500 \mathrm{~m}$ per 1,000 years.

From the southern border of Kuwait, forty-five ${ }^{14} \mathrm{C}$ dates are available, though as yet unpublished. Dating of the sabkha sequences in Al-Khiran indicates a range of $8540-$ $7650 \pm 70 \mathrm{yBP}$ for the beginning of the marine transgression just above the desert sands. This reached a maximum around $4730-4530 \pm 60 \mathrm{yBP}$ in this area. The limit reached by the advancing sea was about $5 \mathrm{~km}$ from the present shoreline. Since then the intertidal and supratidal sediments have prograded to produce the sabkhas of this area.

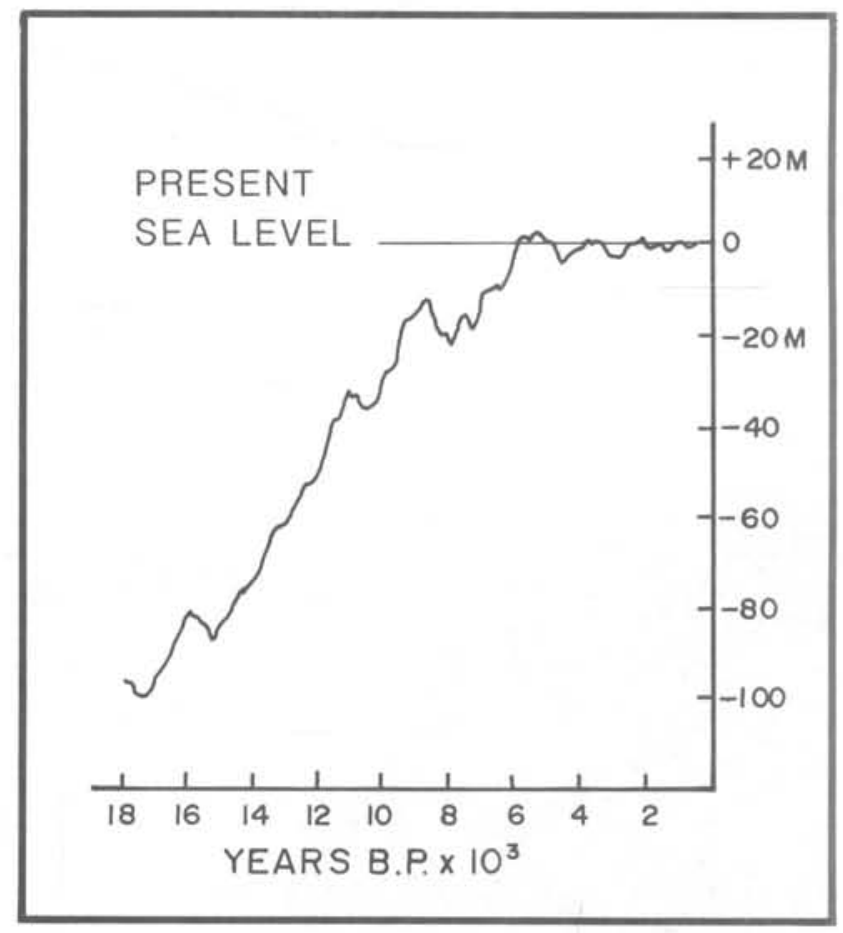

Figure 7: Probable eustatic sea-level changes in the northwestern Arabian Gulf since the last glacial maximum (after A1-Asfour, 1982). 


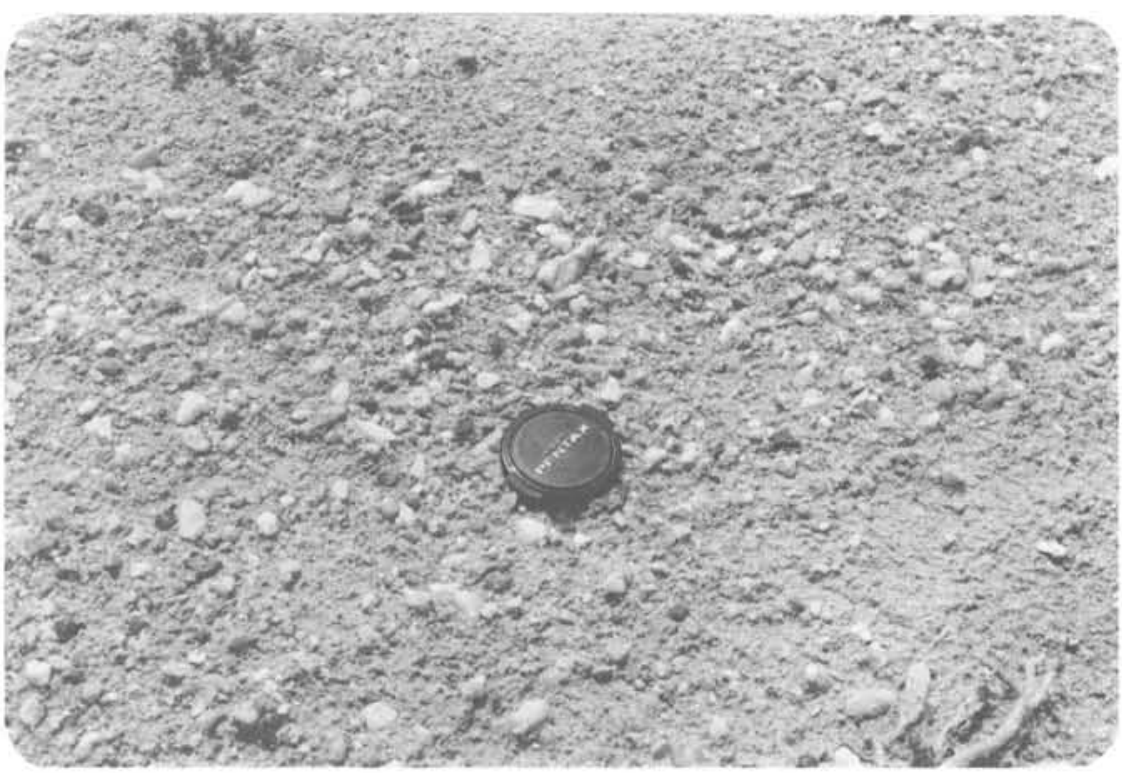

Figure 8: Fluvial gravels deposited by sheet floods during a Pleistocene pluvial phase. $13 \mathrm{~km}$ inland from the coast of southern Kuwait.

to their field occurrence and textural characteristics: eolian, residual, playa, desert plain, alluvial fan and coastal deposits.

The geomorphological and sedimentological evolution of the continental zone has been strongly influenced by Pleistocene pluvial events. It is now well established that a much wetter and humid climate than today dominated the sedimentary environment of the northern Arabian peninsula between 11,000 and 60,000 yBP (Chapman, 1971; Al-Sayari and Zotl, 1978).

During "early to mid-Pleistocene" time, a single structural-geomorphic feature, the Wadi Al-Batin fluvial system, controlled sediment distri-

To the west the transgression was limited by topographic barriers consisting of fluvial-eolian sand bodies that ring the sabkhas along the coastal zone. As a consequence, in many areas, the desert sediments reach all the way to the coast, isolating the sabkhas from each other. Four lithified, oolitic beach-dune ridges (Fig. 5) trailing the sabkha have been dated at $5500-2320 \pm 70 \mathrm{yBP}$, and the modern ridge at $2190 \pm$ $70 \mathrm{yBP}$. These ages agree very well with the data of Al-Asfour (1982) and Al-Zamel (1985) from the head of the Gulf.

The data from southern Kuwait indieate annual progradation rates of $1.5-2 \mathrm{~m}$ and a maximum sea-level of $1.6-2.5 \mathrm{~m}$ higher than today. The ${ }^{14} \mathrm{C}$ dates from Kuwait are also in agreement with Quaternary dates from Qatar, Abu Dhabi, Oman and Iran (Evans et al., 1969; Vita-Finzi, 1969, 1973, 1975; Purser, 1973).

\section{The Continental Zone}

The desert terrain of the northern Arabian Peninsula has not yet been systematically investigated. However, an excellent summary of the geomorphology and surface deposits is given by Khalaf and others (1984) who produced a "sedimentomorphic" map for the entire State of Kuwait at $1: 100,000$. They classified the Quaternary deposits that blanket the entire country into six major classes according

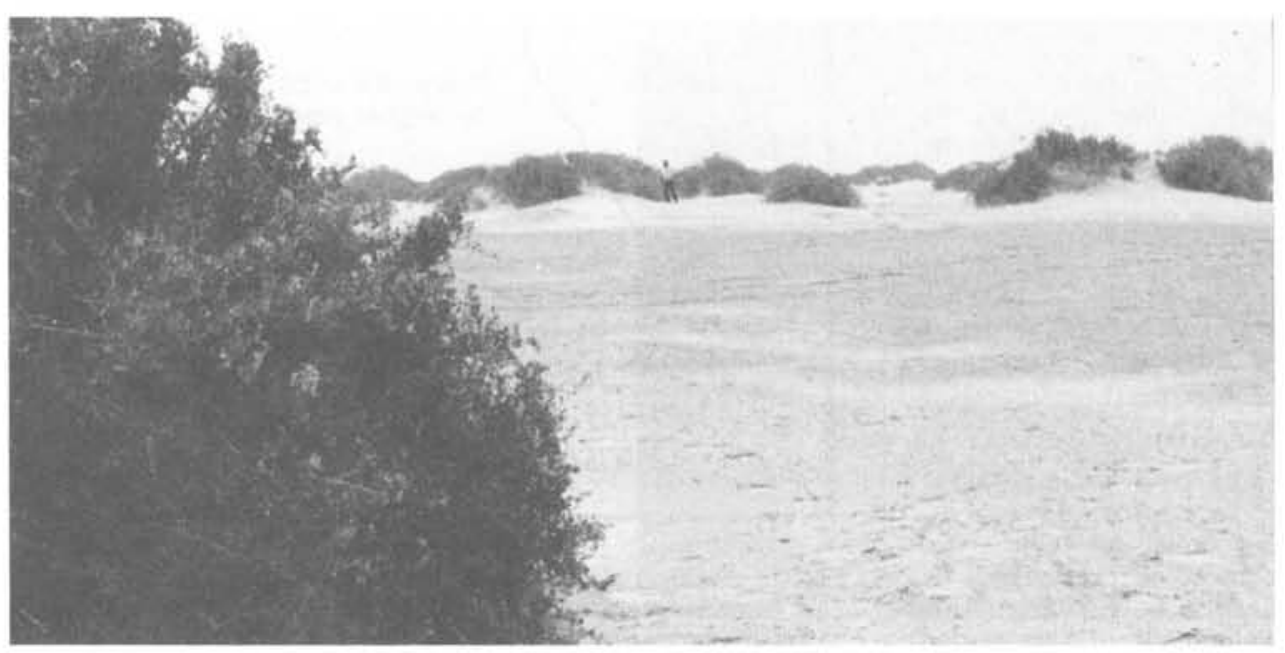

bution in northern Arabia (Fig. 1). This system extends in a $\mathrm{N} 35^{\circ} \mathrm{E}$ direction over a distance of some $80 \mathrm{~km}$ in the western boundary of the State of Kuwait and can be traced for another $700 \mathrm{~km}$ upstream to Saudi Arabia as the Wadi Al-Rimah. About a third of Wadi Al-Batin is covered with Tertiary and Quaternary gravels derived from igneous and metamorphic rocks (Al-Sarawi, 1978), transported from interior Arabia during Pleistocene pluvial times, and spread as an extensive sheet over an earlier erosion surface (Fig. 8). These deposits are represented in Kuwait and Iraq by the Dibdibba Formation. The gravels can be traced northeast into the Gulf itself and were deposited there at a time when sealevel was low and much of the basin was emergent (Al-Asfour, 1982).

Geophysical investigations show that a system of fractures and normal faults affecting Eocene, Miocene and possibly Pleistocene sedimentary strata is also present in the Wadi Al-Batin region (Al-Sarawi, 1980). All fracture systems trend NE-SW, similar to that of a large part of the Saudi Arabian fault system (Al-Sayari and Zotl, 1978). This tectonically controlled morphologic pattern was subdued by the deposition of Pleistocene gravels, but many have been locally rejuvenated by Quaternary tectonic adjustments on the Iranian side.

Eolian deposits consisting of sand sheets, sand dunes and drifts and wadi fills cover about $50-60 \%$ of the surface area of Kuwait. The most common are sand sheets averaging 1-2 $\mathrm{m}$ thick and invariably associated with residual gravel deposits. The largest, the Al-Huwaimilliyah sand sheet in northwest Kuwait is associated with several transverse dune belts.

Figure 9: Small nebkha
dunes within evaporitic
pans in southern Kuwait
(area of high net wind
deflation and low sand
supply).


In the absence of suitable source areas, the desert sands are regarded as largely derived from the reworking of the Pleistocene fluvial deposits that blanket the northern part of the Arabian peninsula. In this area the eolian system is very starved of sand in relation to the available wind energy, and consequently it is one of high net wind deflation.

There are two types of playa-like depressions within the desert terrain, which are ideally described by the local Arabic terms "khabrat" and "mamlahat" (Holm, 1960). Khabrats are small deflated depressions in the wadi drainage systems in the north of the country and are elongated parallel to the general trend of the Wadi Al-Batin drainage system. Their fill is mainly silt and mud, and there are no evaporite minerals.

The mamlahats originated as deflation hollows, which developed into ephemeral lakes during Pleistocene pluvial times. They are filled mainly by sand, silt and micritic calcite, and they contain diagenetic gypsum precipitated within the sediments (Gunatilaka and Mwango, in press). Mamlahats have been called continental sabkha pans and are the equivalents of the continental sabkhas of the southern Arabian peninsula. Their occurrence, which is mainly restricted to southern Kuwait, and preservation are dependent on rising water-table conditions. The only dunes, nebkhas, are halophyte-associated and are confined to these pans (Fig. 9).

Desert plain and alluvial fan deposits consisting of polygenetic Quaternary sediments cover more than $20 \%$ of the desert surface of Kuwait (Khalaf et al., 1984). They are composed of a mixture of sand, silt and gravels and some minor clay fractions deposited as sheet floods on plains and shallow depressions, and subsequently reworked by wind. Slope deposits formed by mass-wasting processes and alluvial fans that originate by ephemeral fluvial processes are common along the Jal Az-Zor coastal plain and escarpment (Fig. 1), where they interfinger with coastal sabkha deposits and coastal dune belts. Finally, various duricrust surfaces (mostly calcretes and gypcretes) are present in many of the continental environments of Kuwait.

\section{The Hydrological Regime}

Kuwait produces its drinking water largely by desalination of seawater. The country is, therefore, interested in exploiting all available groundwater, both freshwater for drinking and brackish-water for irrigation. A considerable amount of hydrological work has been done over the years in Kuwait, but published studies are rare (Omar et al., 1981; Al-Ruwaih, 1984). Much of the data are contained in the annual reports of the Kuwait Ministry of Electricity and Water Supply, in a report by the Parsons Corporation (1963), and in unpublished graduate theses by Al-Hajji (1976) and Al-Ruwaih (1980).

The Tertiary Kuwait Group (some $450 \mathrm{~m}$ of sand, gravel, marls and occasional limestone and shale beds divided into the Dibdibba, Lower Fars and Ghar Formations) is exposed at the surface over most of Kuwait. An erosional unconformity separates this Group from the underlying Hasa Group, consisting of the Middle Eocene Dammam Formation (some $200 \mathrm{~m}$ of dense, massive anhydrite and limestone) and the Paleocene Umm er Radhuma Formation (up to $430 \mathrm{~m}$ of limestone, dolomite and anhydrite). The Dammam and Dibdibba Formations are the main aquifers in Kuwait, though their lithological heterogeneity causes considerable variation in hydrological character. The pattern of groundwater flow in the aquifers is shown in Figure 10 from which it can be seen that the entire aquifer complex originates in Saudi Arabia.

In the Raudhatain and Umm Al-Aish water fields in the north of Kuwait, the main aquifer is the Dibdibba sands and gravels. Here perched freshwater lenses occur. The Raudhatain area has an annual recharge potential of 1.5 million $\mathrm{m}^{3}$. This field was commissioned in 1963 and the yearly production from the upper freshwater zone (of salinity $300 \mathrm{mgl}^{-1}$ ) in 1980 was $18,000 \mathrm{~m}^{3}$ of mineral water. $\mathrm{Umm}$ Al-Aish produces currently each year $80,000 \mathrm{~m}^{3}$ of water. Hydraulic conductivity decreases with depth due to increasing cementation, but all aquifers are connected with each other and with the underlying, highly karstic Damman aquifer (the most productive of all brackish-water sources). The underlying Rus For mation is an aquiclude.

Regionally, within both aquifers the salinity of the water increases from brackish in the southwest to salty and brines in the northeast (Omar et al., 1981). The largest fields of Al-Sulaibiyah and Al-Shigaya exploit brackish water. (salinity 2,500-1 0,000 $\mathrm{mgl}^{-1}$ ) of the $\mathrm{SO}_{4}-\mathrm{Na}$ type, becoming $\mathrm{Cl}-\mathrm{Mg}$ and eventually $\mathrm{Cl}-\mathrm{Ca}$ type in the northeast where salinities reach $150,000 \mathrm{mgl}^{-1}$. The freshwaters of the two northern fields are of the $\mathrm{Na}-\mathrm{HCO}_{3}, \mathrm{Ca}-\mathrm{HCO}_{3}$ and $\mathrm{Ca}-\mathrm{SO}_{4}$ type with salinities of $300-1,550 \mathrm{mgl}^{-1}$ (Al-Ruwaih, 1984).

Much recent work has been done on the stable isotopes 180 , $\mathrm{D}$ and $34_{\mathrm{S}}$ of these groundwaters (Abusada, 1982; Robinson and Al-Ruwaih, 1985; Robinson et al., in press). The Raudhatain and $\mathrm{Umm} \mathrm{Al}$-Aish waters appear to be derived from local precipitation and have not undergone any significant evaporation or isotopic exchange with aquifer rocks. The isotopic compositions of the Neogene and Dammam Formation waters show a depletion in the heavy isotopes $\left(\delta^{18} \mathrm{O}=4.2 \%\right.$ and $\delta \mathrm{D}=-34 \%$ Abusada, op.cit. $)$ compared to the more recent groundwaters. Carbon-14 analyses of the Dammam waters from southwest Kuwait indicate a maximum age of 40,000 years, but most of the waters sampled from the Arabian Shelf range from $8000-$ 32,000 years old.

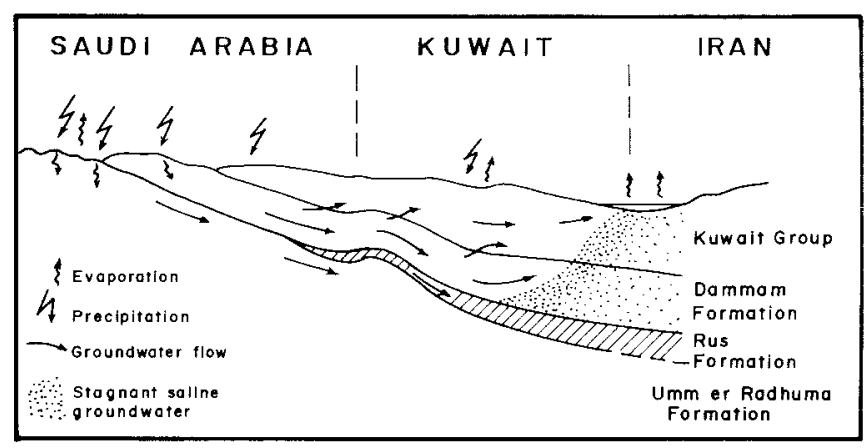

Figure 10: Schematic diagram showing regional groundwater flow in the main aquifers of Kuwait (after Omar et al., 1981).

The Kuwait paleowaters are all old formation waters and were probably derived during the cooler, moist pluvial period present in Arabia between 11,000 and $60,000 \mathrm{yBP}$ (Chapman, 1971). These waters may have been modified somewhat by such processes as mixing with brines or surface waters, evaporation, hyperfiltration and oxygen isotope exchange with rocks (Robinson and Al-Ruwaih, 1985). Surface evaporation of these waters in sabkhas produces sabkha waters with characteristic isotopic compositions (Robinson et al., 1983).

There is no evidence from the isotopic data for large scale mixing of paleowaters with freshwaters (except in Wafra where the data suggest mixing of evaporated formation waters and recent recharge). The coastal sabkha waters represent a mixture of highly evaporated formation water and highly evaporated seawater. The data also indicate that in the absence of marine flood-recharge of sabkhas today, the hydrological regime is almost totally controlled by continental groundwater influx. As sabkhas prograde, the 


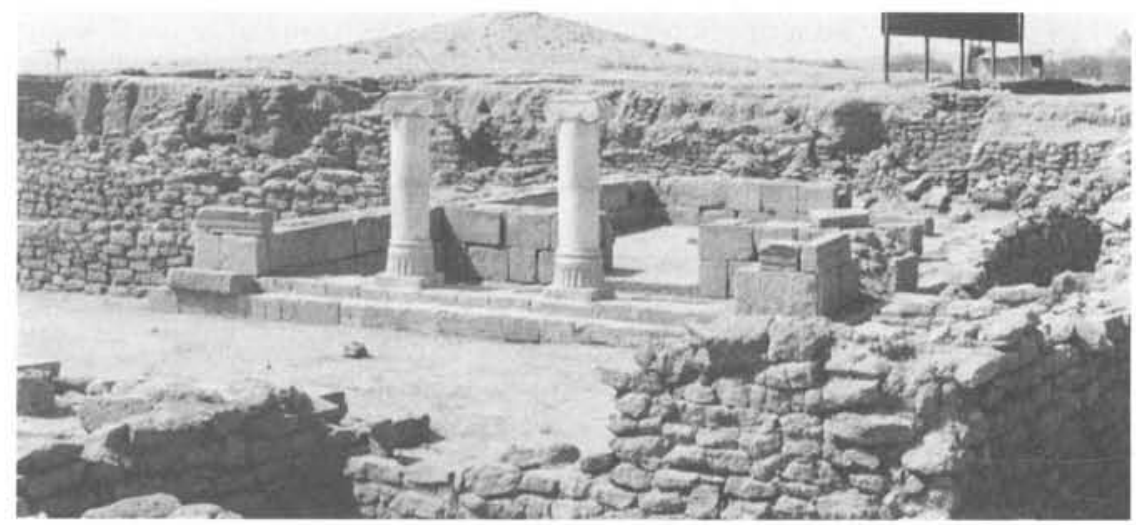

The Gulf basin continues into Iraq as the Mesopotamian trough, a structural/sedimentological entity also associated with the Zagros foredeep region. The position of Kuwait is thus critical, for it is here that the marine facies passes laterally northwest into the fluvial sediments of the Mesopotamian plain. Moreover, it is becoming increasingly apparent that the eolian contribution to the sediment budget of the northern Gulf basin is of the same order of magnitude as that by fluvial sources.

The location of the Shatt Al-Arab delta is tectonically controlled. Delta advance and retreat were related to Quaternary eustatic sea-level changes,

Figure 11: Remains of Hellenic temple in Failaka Island (about $4000 \mathrm{yBP}$ ). The main structure is built with an oolite-rich limestone showing oomouldic porosity.

marine-derived brines are gradually displaced by influxing continental waters. This has important implications for the origin of evaporite minerals in sabkhas.

\section{Archaeological Findings}

Two and possibly three new archaeological sites of regional importance have been discovered during the last three years, during our systematic sedimentological field work. Pottery fragments belonging to the Al-Obaid period (4th millenium B.C., about 5400-7000 yBP) and Islamic period (10th-12th centuries A.D.) were found on an old gravel spit within the sabkha flat, along the northern coastline (Reda, 1986). The third site is at the extremity of the southern coastal zone and contains suspected shell middens (oyster shells belong to the genus Pinctada) at the lower levels of a Holocene oolitic beach-dune ridge. The ridge started off as an offshore ooid-bar (with landward dipping cross-strata), and the middens are always found on the back-barrier side of the present day lagoonal-sabkha.

Two ${ }^{14} \mathrm{C}$ dates of approximately $5500 \mathrm{yBP}$ for the host oolite and about $5000 \mathrm{yBP}$ for the shells indicate that the middens were associated with the later stages of the Holocene transgression. Since the use of pearls is unknown from this time, it is likely that the oysters were used for food by a migrating, presumably fishing community. The older of the northern sites is probably of the same antiquity and may have been inhabited by a similar community. A wellestablished archaeological site (eirea. 1200-3000 B.C.) with a large Hellenic temple, a garrison, coinage, kilns, etc. is known from Failaka Island about $20 \mathrm{~km}$ offshore from mainland Kuwait (Fig. 11).

\section{Commentary}

Current research on Quaternary sediments in the northern Arabian Gulf fills an important gap in a hitherto poorly known region, thus complimenting the better-studied southern Gulf. Although the sedimentary framework of much of the western coastline of the Gulf can be considered as a variation on a general theme, no particular geographic stretch is truly representative of its entire $10,000 \mathrm{~km}$ length.

The northern region is situated in a climatic-geomorphic setting somewhat different from that of the classical area of the Trucial Coast of the UAE, and it shows the interaction of two contrasting styles of sedimentation. It may be the only modern example of an area containing a clastic sabkha and an arid zone delta bordering a hypersaline marine basin, and representing sedimentation in a low-relief desert margin system. with the consequent shifting of the loci of carbonate production. A beginning can now be made towards linking the record of eustatic sea-level fluctuations and Quaternary climatic changes in the entire Gulf basin and continental areas.

The evolution of the desert terrain and the hydrological system is directly related to Pleistocene pluvial events. The northern part of this terrain is highly sand-undersaturated in relation to the available wind energy and is characterized by net deflation and transport; consequently the sediment cover is very thin. In contrast, net deposition typifies the southern parts of the Peninsula, as exemplified by the great eolian sand-seas of the Rub Al-Khali (The Empty Quarter). The southern boundary of Kuwait is also the northernmost limit of coral-reefs and the evaporite belt containing anhydrite in the Gulf.

The scope can now be extended of the Trucial Coast sabkha model, which has been heavily used in environmental interpretations. It is hoped that this work will be of interest to geologists in the petroleum industry who have been dealing with ancient analogues containing similar, potentially oil-bearing sediments, and also in paleogeographic syntheses. The juxtaposition of organic-rich clastic sediments and potentially favourable carbonate sediments provides for interesting possibilities in exploration modelling. Such modelling should take into account the evolution of the continental terrains and paleohydrological systems.

Future researchers need to concentrate upon the delta region, the northeastern shorelines, the Iranian side of the Gulf and offshore regions. The distribution and ecology of the marine fauna and flora in relation to sedimentation and environmental factors is not sufficiently known. A significant amount of work is presently being done on environmental pollution in the Gulf as it is one of the busiest waterways in the world. Hence it is imperative that relevant baseline data (e.g. on organic/inorganic pollutants, heavy metals, desalination and sewage effluents) are gathered from the marine regions.

\section{Acknowledgements}

Much of the work summarized here will be published as an AAPG Memoir edited by the author and G. Evans. Thanks are due to David Almond for comments and suggestions. This paper provides a background to an international symposium on the delta and Gulf to be held in Kuwait in February 1987.

Dr. A. Gunatilaka teaches sedimentology at the Department of Geology, Kuwait University. Previously he taught at the Universities of Sri Lanka and Zambia. His main research interests are carbonate and evaporite sediments and their diagenesis, particularly in Kuwait.

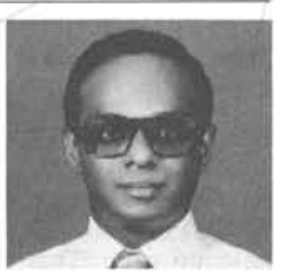




\section{References}

Abusada, S.M., 1982. Interpretation of environmental isotope data of Kuwait groundwater. Journal of Gulf and Arabian Peninsula Studies, v. 2 , p. $80-92$.

Al-Asfour, T.A., 1982. Changing sea-level along the north coast of Kuwait Bay. Kegan Paul International, London, $250 \mathrm{p}$.

Al-Bakri, D., Khalaf, E. and Al-Cihadban, A., 1984. Mineralogy, genesis, and sources of surficial sediments in the Kuwait marine environment, Northern Arabian Gulf. Journal of Sedimentary Petrology, v. 54, no. 4 , p. 1266-1279.

Al-Hajii, Y.Y., 1976. A quantitative hydrological study of Field "A", South of Kuwait. M.S. thesis, Ohio University, Athens, Ohio, U.S.A., $116 \mathrm{p}$.

Al-kuwaih, E.M., 1980. Hydrogeology of AI-Sulaibiya well field, southwest Kuwait. Ph.D. thesis, University College, London, U.K., $390 \mathrm{p}$.

Al-kuwaih, F.M., 1984. Groundwater chemistry of Dibdibba Eormation, North Kuwait. Ground Water, v. 22 , no. 4, p. 412-417.

Al-Sarawi, A.W., 1978. General geology and structural evolution of Wadi Al-Batin, Kuwait. Vis. thesis, Ohio University, Athens, Ohio, U.S.A., $88 \mathrm{p}$.

Al-Sarawi, A.M., 1980. Tertiary faulting beneath wadi Al-Batin, Kuwait. Geological Society of America Bulletin, Part 1, v. 91, no. 10 , p. 610-618.

Al-Sayari, S.S. and Zotl, J.G. (eds.), 1978. Quaternary period in Saudi Arabia, v. 1 , Sedimentological, hydrogeological, hydrochemical, geomorphological, and climatological investigations in Central and Eastern Saudi Arabia. Springer-Verlag, Austria, $31 \mathrm{lp}$.

Al-Zamel, A.Z., 1983. Geology and Uceanography of Recent Sediments of Jazirat Bubiyan and Kas AsSabiyah, Kuwait. Ph.D. thesis, Sheffield University, U.K., v. I \& Ii, $336 \mathrm{p}$.

Al-Zamel, A.Z., 1985. Occurrence and age of submarine peat in the Euphrates-Tigris delta. SEPM Midyear meeting, Golden, Colorado, U.S.A. Abstracts, p. 4.

Audley-Charles, M.G., Curray, J.k. and Evans, G., 1977. Location of major deltas. Cieology, v. 5 , no. 6 , p. $341-344$.

Bally, A.W., 1975. A geodynamic scenario tor hydrocarbon occurrences: Proceedings of the World Petroleurn Congress, T'okyo, v. 2, no. 9, p. 33-44.

Behbehani, A.S.K., 1980. Structural and petroraphic analysis of the Nishrif member of the Magwa Formation in the Hout, Uorra and Khafji Oil fields, offshore Kuwait - Saudi Arabia divided Neutral Zone. M.S. thesis, University of Toledo, Ohio, U.S.A., $40 \mathrm{p}$.

Berry, R.W., Brophy, C.P. and Naqash, A., 1970. Vineralogy of the suspended sediment in the Tigris, Euphrates and Shatt-Al-Arab rivers of Iraq, and the recent history of the fvesopotamian plain. Journal of Sedimentary Petrology, v. 40 , no. 1, p. 131-139.

Chapman, R.W., 1971. Climatic changes and the evolution of landforms in the eastern province of Saudi Arabia. Geological Society of America Bulletin, v. 82 , no. 10, p. 2713-2728.

Ellis, J.P. and Vlilliman, J.D., 1985. Calcium carbonate suspended in the Arabian Gulf and Red Sea waters: Biogenic and detrital, not "chemogenic". Journal of Sedimentary $\mathrm{Pe}^{-}$ trology, v. 55, no. 6, p. 805-808.

Evans, G., Schmidt, V., Bush, P. and Nelson, H., 1969. Stratigraphy and geologic history of the Sabkha, Abu Uhabi, Persian Gulf. Lithification of Carbonate Sediments, 1, Sedimentology, v. 12 , no. $1-2$, p. 145-159.

Fairbridge, R.W., 1961. Eustatic Changes in sea level. In: Physies and Chemistry of the Earth, v. 4, p. 99-1 85, Oxford, Pergamon Press.

Godwin, H. and willis, Ł..H., 1959. Cambridge University Natural Radiocarbon Veasurements I. Radiocarbon 1, American Journal of science Radiocarbon Supplement, p. 63-75.

(iunatilaka, A., Saleh, A. and Al-Temeemi, A., 1980. Plant controlled supratidal anhydrite from Al-Khiran, Kuwait. Nature, v. 288, no. 5788 , p. $257-260$.

Gunatilaka, A., Saleh, A., Al-l'emeemi, A. and Nassar, N., 1984. Occurrence of subtidal dolomite in a hypersaline lagoon, kuwait. Nature, v. 311 , no. 5985 , p. $450-452$.

Gunatilaka, A., Saleh, A. and Al-Temeemi, A., 1985. Sulfate reduction and dolomitization in a Holocene lagoon, Kuwait. SEPIV Midyear meeting, Golden, Colorado, U.S.A. Abstracts. p. 33

Gunatilaka, A. and Wwango, S.B., in press. Continental sabkha-pan and associated nebkha complexes in the southern desert of Kuwait. Journal of the Geological Society, London. Special Issue on Desert Sediments. I. Reid and L. Frostick (eds.).

Holm, U.A., 1960. Desert geomorphology in the Arabian Peninsula. Seience, v. 132, p. $1369-1379$.

Hudson, K.G.S., Eames, F.E. and Wilkins, G.L. 1957. The fauna of some recent marine deposits near Basrah, Iraq. Geological Magazine, v. y4, no. 5 , p. 393-401

Kamen-Kaye, M., 1970. Geology and productivity of the Persian Gulf Synclinorium. American Association of Petroleum Geologists Bulletin, v. 54, no. 12, p. 2371-2394.

Khalaf, F.I., Kadio, L., Gharib, I., AlHashash, W., Al-Saleh, S, and Al-Kadi, A, 1980. Dust fallout in Kuwait. Kuwait Institute for Scientific Research. Technical Report. Kuwait, KISR/PP1 108/EES-RF-80l6.

Khalaf, F.l., Al-Ghadban, A., Al-Saleh, S. and Al-Harmi, L., 1982. Sedimentology and mineralogy of Kuwait Bay bottom sediments, Kuwait, Arabian Gulf. Marine Geology, v. 46, p. 71-99.

Khalaf, F.I., Gharib, I. M. and Al-Hashash, W..Z. 1984. Types and characteristics of the Recent surface deposits of Kuwait, Arabian Gulf. Journal of Arid Environments, v. 7, p. y-33.

Kinsman, D.J.J., 1969. Yodes of formation, sedimentary ussociations and diagnostic features of shallow water and supratidal evaporites. American Association of Petroleum Geologists Bulletin, v. 53 , p. $830-840$.

Larsen, C.E. and Evans, G., 1978. The Holocene geological nistory of the TigrisEuphrates-Karun delta. In: Brice, W.C. (ed.), The Environmental History of the near and Widdle East since the Last Ice Age. Academic Press, London, U.K. $384 \mathrm{p}$.

Lees, G.M. and Falcon, N.L., 1952. The geographical history of the Vesopotamian Plains. Geographical Journal, v. 118, p. 24-39.

Vinistry of Public Health, 1978. Dust fallout in Kuwait. Occupational Health and Industrial Section, Public Health and Planning Department, Kuwait. 184p.

Wurris, R.J., 1980. Widdle East: Stratigraphic evolution and oil habitat. American Association of Petroleum Geologists Bulletin, v. 64, no. 5, p. 597-618.

Mwango, S.B., 1986. Sedimentological studies of eolian terrains in southern Kuwait. V.S. thesis, Kuwait University, $168 p$.
Omar, S.S., Al-Yaqubi, A. and Senay, Y., 1981. Geology and groundwater hydrology of the State of Kuwait. Journal of Gulf and $A$ rabian Peninsula Studies, v. 1, p. 39-51.

Parsons Corporation, 1963. Groundwater resources of kuwait. vol. I and II. Los Angeles. Unpublished.

Picha, R., 1978. Depositional and diagenetic history of Pleistocene and fiolocene oolitic sediments and sabkhas in Kuwait, Persian Gulf. Sedimentology, v. 25 , no. 3, p. 427-450.

Picha, F. and Saleh, A.A.W., 1977. Quaternapy sediments in Kuwait. Journal of the University of Kuwait (Science), v. 4, p. 169-184.

Pilkey, O.H, and Noble, U., 1966. Carbonat and clay mineralogy of the Persian Gulf. DeepSea Kesearch, v. 13, no. 1, p. 1-16.

Purser, B.H. (ed.), 1973. The Persian Guif: Holocene carbonate sedimentation and (iiarenesis in a shallow epicontinental sea. Springer-Verlag, Berlin, $47 \mathrm{lp}$.

Purser, B.H., 1985. Coastal evaporite systents. In: Friedman, G.î. and Krumbein, W.E. (eds.), Ecological Studies, v. 53. Ilypersaline Leosystems. Springer-Verlag, Berlin, p. 72-102.

Reda, A.A., 1986. A reconnaissance study of a clastic coastal sabkha, Bahra area, norther Kuwait. M.S. thesis, Kuwait University, 245p.

Robinson, B.W., Stewart, M.k. and Gunatilaka, A., 1983. Sulphate and water stable isotopes and the origin of ground and sabkhawaters in kuwait. 4th International symposium on WaterRock Interaction, Vlisasa, Japan. Extendexd abstracts, p. 409-412.

Robinson, B.W., Stewart, W.K. and Gunatilak, $A$, in press. Use of sulfur and other stable isotopes in environmental studies of regional groundwater flow and sulphate mineral formation in Kuwait. In: Krouse, H. and Grinenko, $V$. (eds.), Use of isotopes in sulfur cycle studies. SCOPE Report. John Wiley * Sons, New York.

Robinson, B, and Al-Ruwain, F., 1985. The stable-isotopic composition of water and sulphate from the Kaudhatain and Umm Al-Aish freshwater fields, kuwait. Chemical Geology (Isotope Geoscience Section), v. 58, no. 1-2, p. 129-136.

Saleh, A., 1975. Pleistocene and Holocene oolitic sediments in the Al-khiran area, Kuwait. M.s. thesis, Kuwait University, 125p.

Saleh, A., 1979. Recent algal mats and Quaiernary carbonate sediments of Al-Khiran, Kuwait. Ph. L, thesis, Imperial College, London, $242 \mathrm{p}$.

Sarnthein, M., 1972. Sediments and history of the postglacial transgression in the Persian Ciult and northwest Gulf of Oman. Marine Geology, v. 12 , no. 4, p. $245-266$.

Schlumberger Well Evaluation Review, 1986. The land of giants. v. 1, no. 1, p. 6-21.

Sengor, A. M.C., 1985. The story of Tethys: how many wives did Oceanus have? Episodes, v.8, no. 1, p.3-12.

Stoffers, P. and Ross, D.A., 1979. Late pleistocene and Holocene sedimentation in thic Persian Gulf - lulf of Oman. Sedimentary Geology, v. 23, no. 1-4, p. 181-208.

Vita-Finzi, C., 1969. Late Quaternary alluvi:1 chronology of Iran. Geologische Rundschali, v. 58 , no. 3 , p. $951-973$.

Vita-Finzi, C., 1973. Late Quaternary subsidence, In: Cornelius, P.F.S., "The Musandarn Expedition. 1971-72. Scientific Results, Part I, Geographical Journal, v. 139, pt. 3, p. 414-421.

Vita-Finzi, C., 1975. Quaternary deposits in the Iranian Wakran. Geographical Journal, v. 141, pt. 3 , p. $415-420$. 